\title{
Isolation of Karanjin from Pongamia Pinnata and Its Identification by Difference Analytical Techniques
}

\author{
Sushil Kumar Dhanmane \\ Chemistry \\ Fergusson College \\ Savitribai Phule Pune University \\ Pune, India \\ Sushnmr@gmail.com
}

\author{
Faisal A. Salih \\ Medical Laboratory \\ Technical College of Health \\ Sulaimani Polytechnic University \\ Sulaymaniyah , Kurdistan region, Iraq \\ Faisal.salih@spu.edu.iq
}

\begin{abstract}
Karanjin is the medicinal drug that used as anti- inflammatory and anti-cancer. The object of this study is to isolate karanjin in karanja (pongamia pinnata Linn.) seed oil. The seed oil was subjected to triple petroleum with continuously constant shaking for first $\mathbf{4 8}$ hours, 24 hours for each second and third extraction then separated under reduced pressure at $50^{\circ} \mathrm{C}$ on rotatory evaporate to get yellow viscous oil. Separate non-fatty components using ethanol solvent and reduced under $50^{\circ} \mathrm{C}$ with pressure to get $(43.33 \mathrm{~g})$ yellow oil. The oil was kept for 3 days at $45^{\circ} \mathrm{C}$ in refrigerator white deposited at bottom of oil, the residue recrystallized with methanol it should be done fast and carefully to prevent solubility of karanjin in methanol partially, the purity of isolated karanjin was found to be (99.623\%). From TLC, HPL, IR, 1HNMR, 13CNMR spectra data, structure elucidation was done and the structure was confirmed as karanjin.
\end{abstract}

Keywords: Karanjin, pongamia pinnata, Karanja oil, medicinal plant.

\section{INTRODUCTION}

Pongamia pinnata Pierre belonging to the family Fabaceae (Papilionaceae). It is also called Derris indica and Pongamia glabra [1]. Pongamia piñata is a medium in sized and evergreen tree and a short bole. The tree is planted for shade and is grown as ornamental tree [2].

Classification of Pongamia pinnata,

Botanical Classification

Kingdom: Plantae,

Division: Magnoliophyta,

Class: Magnoliopsida,

Order: Fabales,

Family: Fabaceae,

Genus: Pongamia,

Species: P. pinnata,

Common name is Karanja [2].

Botanical Name

Pongamia pinnata (L.) Pierre

Synonyms

Derris indica (Lam.) Bennett
Millettia novo-guineensis Kane. and Hat.

Pongamia glabra Vent.

Pongamia pinnata Merr.

- Native

Bangladesh, India, Myanmar, Nepal, Thailand.

- Exotic

Australia, China, Egypt, Fiji, Indonesia, Japan, Malaysia, Mauritius, New Zeeland, Pakistan, Philippines, Seychelles, Solomon Islands, Sri Lanka, Sudan, United States of America [3] .

\section{- Botanical description of P. pinnata}

Karanja is a drought tolerant, semi-deciduous and leguminous tree. A spreading crown up to $18 \mathrm{~m}$ height or sometimes even more and $(1.5 \mathrm{~m})$ in girth. Pod are compressed, woody, indehiscent, yellowish-gray when ripe , varying in size and shape $(4.0-7.5 \mathrm{~cm})$ long and ( $1.7-3.2 \mathrm{~cm}$ ) broad, bark grayish green or brown, smooth or covered with tubercles, leaves compound, imparipinnate, leaflets opposite, 5-9 in number, ovate or elliptic; flowers white tinged with pink or violet, fragrant, in axillary racemes, , seeds usually one, rarely two, elliptical or reniform $(1.7-2.0 \mathrm{~cm})$ long and ( $1.2-$ $1.8 \mathrm{~cm}$ ) broad, wrinkled with reddish brown leathery testa. Brawn in color and poisonous in fact which should be considered in placing the tree in the landscape if many children present [4-5]. The potential of this oil as a substitute for diesel [6] and as lubricating in tuning industries is recognized [7] .

\section{- Distribution:}

Karanja is believed to be originated in India and Distributed throughout India in tidal and beach forest, often as a mangrove plant [8]. It is grow in the hills of south India up to elevation of about 1200 meters (4000 feet.) and in the Himalayas up to about 610 meters (2000 feet). It is widely grown from tropical dry to sub-tropical dry forest life zones. It is a shade bearer and is considered to be a good tree for planting in pastures, as grass grows well in its shade. 


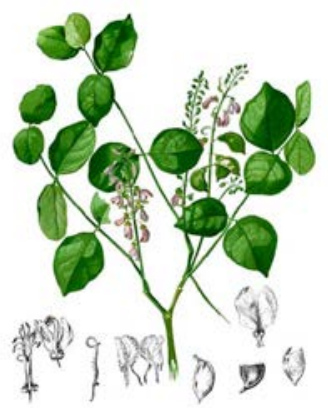

Figure 1A: Pongamia pinnata tree.

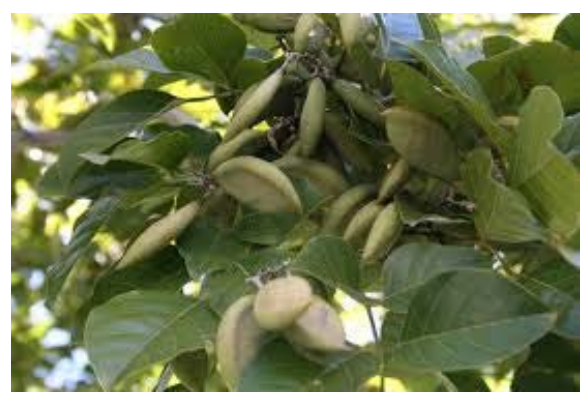

Figure1B: Pongamia pinnata fruit.

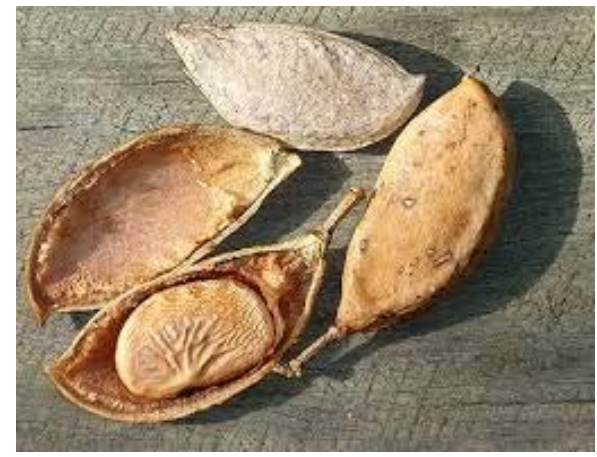

Figure 1C: Pongamia pinnata seeds.

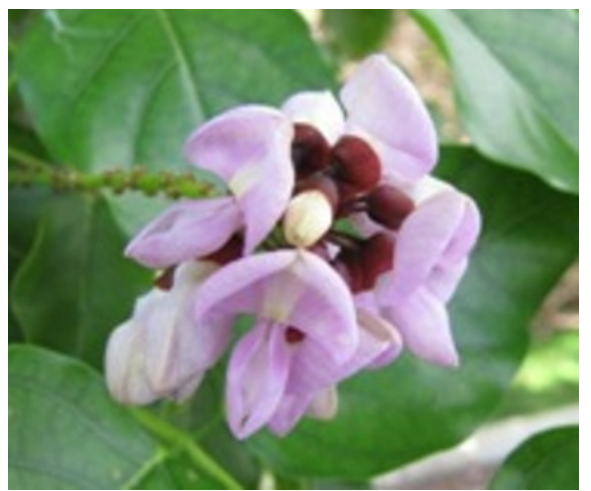

Figure 1D: Pongamia pinnata flower.

The tree is suitable for afforestation especially in watershed areas and drier part of the country. $P$. pinnata is reported to be a native of India, Myanmar, Malaysia and Indonesia [6] that is distributed in tropical Asia, Australia, Polynesia, Philippine Islands [5] Unite state New Zealand, China [6,9].

\section{- Collection of seeds and processing}

The seed collection is prolonged due to nonsynchronization of flowering \& fruiting. Therefore, one time harvesting is usually not possible. The collected pods are dried for 2-3 days in the sun. The kernels are separated from the hell manually by a wooden hammer or manually operated decorticator. However, the electric decorticators of Karanja fruits have also been fabricated and being used for efficient processing. The average seed yields of Karanja is about 40-90 qtl/ha. Properties of Karanja seeds Karanja kernels are reddish brittle in colour. The air-dried kernels contain 19\% moisture, $27-39 \%$ oil, $17.4 \%$ protein $6.6 \%$ starch, $7.3 \%$ crude fibers and $2.3 \%$ ash. The kernels also contain mucilage (13.5\%) and traces of essential oil. In addition, a complex amino acid glabrin is also present.

\section{- Physical-chemical properties and fatty acid composition of Karanja oil.}

It is known as pongam oil in trade. Fresh extracted oil is yellowish orange to brown, getting darkened during storage, having disagreeable odour and bitter quality of oil, the important properties of oil and fatty acids are given below:

\section{Properties of oil}

\begin{tabular}{|c|c|}
\hline Colour & Dark brown \\
\hline Odour & Repulsive \\
\hline Refractive index at $40^{\circ} \mathrm{C}$ & $1.434-1.4790$ \\
\hline Specific quantity at $30^{\circ} \mathrm{C}$ & $0.925-0.940$ \\
\hline Iodine value & $80-96$ \\
\hline Saponification value & $185-195$ \\
\hline Non-saponification value & $2.6-3.0$ \\
\hline
\end{tabular}

Composition of important fatty acids found in Karanja oil

\begin{tabular}{|c|c|}
\hline Palmitic & $3.7-7.9 \%$ \\
\hline Stearic & $2.4-8.9 \%$ \\
\hline Oleic & $44.5-71.3 \%$ \\
\hline Linoleic & $10.8-18.3 \%$ \\
\hline Lignoceric & $1.1-3.5 \%$ \\
\hline Eicosenoic & $9.5-12.4 \%$ \\
\hline Arachidic & $2.2-4.7 \%$ \\
\hline Bethenic & $4.2-5.3 \%$ \\
\hline
\end{tabular}

\section{- Use of Pongamia pinnata}

The plant known to have a very high medicinal value [11]. The bark skin, leaves, flowers seeds and seed oil are used for medicinal purpose, karanja is used both into internally as well as externally. Bark is known to be the remedy for beriberi, Leaves are actives against microccus and their juce is used for cold cough, diarrhea [3] antibacterial, anti-giardia and anti-virial [12] antihyperammonemic. Its flowers are used for diabetes $[3,13]$ skin disease, renal disorders [13. Externally roots are good for cleaning foul ulcers, cleaning teeth, antiinflammatory [14], gastroprotective anti-stress activity and anti-oxidant [15]. The fruits and sprouts are use in folk remedies for abdominal remedies in India [3]. Seeds 
are anthelmintic, bitter, acrid and carminative [14], inflammation, rheumatism [16], skin disease [11] , pectoral diseases , chronic fever and anemia [17], keloid tumors in sri lanka and powder derived from plants for tumors in Vietnam, skin ailments and the oil of seeds used as an ointment for rheumatism [3] , leucodermal, scabies, herpes [16] against herpes simplex virus type-Í (HSV-1) and type 2 (HSV-2) was evaluated in vivo cell and antibiotics [18] leucocoderma, leprosy, lumbago [13], ulcer protective and healing effects and antiinflammatory activity of alcoholic extract of seeds and root $[13,14]$ high toxic to fish , alcoholic extract of oil showed activity against both Gram positive and Gram negative bacteria [16] , extract of the opulent possess significant anti- diarrhea , anti-fungal , anti-plasmodial, anti ulerogenic, anti-inflammatory and analgesic activities [5] .

\section{- Properties and Activity}

The flower furnishes an aliphatic waxy matter kaempferol, pongamin $\left(\mathrm{C}_{15} \mathrm{H}_{12} \mathrm{O}_{5}\right), \quad \gamma$-sitosterol glucoside, quercertin, neoglabrin (A complex amino acids) resembling glabrin and galbrosaponin $\left(\mathrm{C}_{50} \mathrm{H}_{84} \mathrm{O}_{23}\right)$ [19]. A furanoflavone i.e., pongone has been isolated from flowers [19] .P. pinnata contains flavonoids and other compounds including flavones, furanoflavonoids, chromenoflavone, chromenocalchones, coumarins, flavone glycosides sterol, terpenes and modified phenylalanine dipeptide [20] . The seeds contain 13.5\% mucilage, traces of essential oil and complex amino acids, termed glabrin. Four furanoflavones karanjin, pongapin $\left(\mathrm{C}_{19} \mathrm{H}_{12} \mathrm{O}_{6}\right)$, kanjone $\left(\mathrm{C}_{18} \mathrm{H}_{12} \mathrm{O}_{4}\right)$ and pongaglabrone $\left(\mathrm{C}_{18} \mathrm{H}_{10} \mathrm{O}_{5}\right)$, identified as 3',4'methylenedioxy furano $\left[2^{\prime}, 3^{\prime}, 7,8\right]$ flavone, have been isolated from Indian Karanja seed [21]. Three furanoflavonoids (Pongamosides A, B and C) and a flavonol, glucoside Pongamoside $\mathrm{D}$, have been reported from the n-butanol-soluble fraction of the ethanolic extract P. pinnata fruit [22]. Pongaglabol, a hydroxyfuranoflavone, and aurantiamide acetate, a rarely occurring modified phenylalanine dipeptide, have been isolated together with four furanoflavones (karanjin, lancheolatin B, kanjone and pinnatin) [23]. Two hydroxychalcones - onganones I and II - have been isolated from bark and characterized. Moreover, two phenylpropanoids - Pongapinone A and B - have been isolated from bark of Indonesian karanja plants [24] . Five flavonoids (Pongamone A, B, C, D and E) have been isolated from P. pinnata [25]. Seed is considered useful in the treatment of scabies, leprosy, piles, ulcers, bronchitis and whooping cough [26] . Seeds are mainly valued for their oil, in cosmetic industry and Ayurvedic herbal medicine [27], antihyperglycemic and antilipidperoxidative [29] antiulcer [30], analgesic [28], antimycobacterial [10] and antifilarial activity [17].

\section{METHODS AND MATERIALS}

\section{- Isolation procedure}

Powder of dried kernels (500 g) was suspended in Petroleum ether (1L). The suspension was, then, filtered. Through glutted filter paper and repeated the same procedure twice. Then all the extract was combined and was concentrated under reduced pressure at $50^{\circ}$ on rotatory evaporator to a get yellow viscous oil. The non-fatty components were extracted from yellow viscous oil with ethanol. The ethanol extract was combined and it was concentrate under reduced pressure at $50^{\circ}$ to get a $43.33 \mathrm{~g}$ of yellow oil. The oil was kept for 3 days at $4-5^{\circ}$ in refrigerator. While residue was deposited at the bottom of oil. The oil was decanted and the obtained residue was recrystallized with methanol. TLC was taken but the T.L.C. gave 2 spots on with very small Rf value so the sample on column was loaded approximately $500 \mathrm{mg}$ sample. The column was made up of silica gel having mesh size of 60-120. But still sample did not get separated. The preparative plate chromatography was used. Due to excess loading of sample it got failed. So the sample was recovered whole from preparative plate and then again recrystallization was done. Then TLC was taken. TLC gave a single spot. From this conclusion was drawn that the compound gets rearranged when it exposed to sunlight for (1 or 2) days to give another compound as an impurity.

\section{- TLC}

\section{Test solution}

Extract $2 \mathrm{~g}$ of powdered drug with $15 \mathrm{ml}$ of ethanol in a Soxhlet apparatus for $18 \mathrm{~h}$. Remove the solvent under reduced pressure at $50^{\circ}$ yielding the $0.160 \mathrm{~g}$ crude residue. Dissolve $5 \mathrm{mg}$ of the residue in $5 \mathrm{ml}$ of methanol and use the solution for TLC profiling.

\section{Standard solution}

Dissolve $2 \mathrm{mg}$ of karanjin in $5 \mathrm{ml}$ of methanol.

\section{Solvent system}

Hexane: Ethyl acetate $(80: 20)$

\section{- Procedure for TLC:}

Apply $20 \mu$ l of test solution and $5 \mu \mathrm{l}$ of standard solution separately on a precoated silica gel $60 \mathrm{~F} 254$ TLC plate (E. Merck) of uniform thickness of $0.2 \mathrm{~mm}$. Develop the plate in the solvent system till the solvent rises to a distance of $8 \mathrm{~cm}$.

\section{- HPLC Assay}

HPLC chemical and physical discretion

Chromatographic conditions:

Mobile phase: Acetonitrile (100\%)

Flow rate: $0.5 \mathrm{ml} / \mathrm{min}$

Column: Zorbax Eclipse, XDB, c8, 4.6 mm x 150 mm, reverse phase

Detector: UA Detector at 254 nm

\section{Test Solution}

Extract $2 \mathrm{~g}$ of powdered drug with $15 \mathrm{ml}$ of ethanol in a Soxhlet apparatus for $18 \mathrm{~h}$. Remove the solvent under reduced pressure $50^{\circ}$ yielding the $160 \mathrm{~g}$ crude residue. Dissolve $10 \mathrm{mg}$ of residue in $10 \mathrm{ml}$ of methanol. Filter through $0.45 \mu$ membrane and use the solution for chromatography.

\section{Standard Solution}

Dissolve $3 \mathrm{mg}$ of Karanjin in $10 \mathrm{ml}$ of methanol. From this stock solution prepare a standard solutions of 0.018 , $0.037,0.037,0.075,0.15$ and $0.3 \mathrm{mg} / \mathrm{ml}$ by transferring 
aliquots (0.62, 1.25, 2.5 and $5 \mathrm{ml})$ of stock solution to 10 $\mathrm{ml}$ volumetric flasks and adjusting the volume of each solution to $10 \mathrm{ml}$ with methanol.

\section{Calibration Curve}

Run the HPLC of each of the standard solutions and record the respective peak area. Prepare a calibration curve by polluting peak area vs concentration of Karanjin.

\section{- Procedure for HPLC}

Subject $5 \mu$ of standard and sample solutions to high performance liquid chromatographic system and record the respective peak area for the test solution and the standard solutions.

\section{Results and Discussion}

Different analytical techniques were used to confirm isolated structure of karanjin. White needles, melting point $163-164^{\circ}$, Literature melting point $1161^{\circ}$, Specific Rotation: Not applicable

Solubility Soluble in benzene, ether, chloroform, acetone, alcohol. Practically insoluble in petroleum ether. Elemental analysis C 74.13\%, H 4.03\%, O 21.84\%, expected elemental analysis: C 73.97\%, H $4.14 \%$, O $21.90 \%$<smiles>COc1c(-c2ccccc2)oc2c(ccc3occc32)c1=O</smiles>

Karanjin Structure

\section{- Percentage of the marker compound}

Calculate the amount of Karanjin present in the sample from the calibration curve. The percentage of karanjin ranges from $(0.06 \%$ to $0.08 \%)$ in the sample analyzed and the purity of isolated karanjin was found to be (99.623\%) $400 \mathrm{mg} ; 0.08 \% \mathrm{w} / \mathrm{w}$ of kernels of Pongamia pinnata.

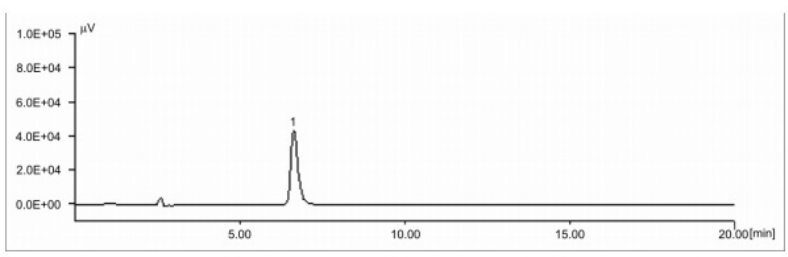

Figure 2: HPLC Chromatogram of Karanjin.

\section{- Characterization of the marker compound UV- VIS Spectrum}

Table 1: UV-VIS spectrum of Karanja.

UV-VIS spectrum indicates absorptions at

$308 \mathrm{~nm}(\dot{\varepsilon}=9.7 \times 10), 260 \mathrm{~nm}(\dot{\varepsilon}=1.61 \times 10)$ and $208(\dot{\varepsilon}=$ $2.21 \times 10)$
Descriptions: The UV spectrum indicates the presence of strong chromophore. The three peaks obtained at 308, 260 and $208 \mathrm{~nm}$ suggest the presence of three chromophoric systems in the structure. This is in complete agreement with the structure

\section{IR Spectrum:}

Table 2: IR spectra of Karanjin.

2930 (C-H stretching),

2851, 1635, 1625, 1605, 1570, 1525, 1409, 1340 (C-O),

$1285,1225,1079,1051,956,795 \mathrm{~cm} 1$

\section{${ }^{1}$ H NMR Spectrum}

Table 3: ${ }^{1} \mathrm{H}$ NMR spectra of Karanjin

\begin{tabular}{|l|}
\hline$\delta 3.9$ (3 H, s, OCH3, H-11), \\
\hline $7.1 \quad(1 \mathrm{H}, \mathrm{m}, \mathrm{H}-4 ”)$, \\
\hline 7.14 (1H, d, J=2 Hz, H-3'), \\
\hline 7.45 (1H, m, H=5”), \\
\hline 7.49 (1H, m H=3”), \\
\hline 7.50 (1H, m,H=6”), \\
\hline 7.70 (1H, m, H=2”), \\
\hline 7.75 (1 H, d, J=2Hz, H=2'), \\
\hline 8.10 (1Hd, J=8.5 Hz, H=6), \\
\hline 8.20 (1H, d, J=8.5 Hz, H=5), \\
\hline
\end{tabular}

\section{${ }^{13}$ C NMR Spectrum}

Table 4: ${ }^{13} \mathrm{C}$ NMR spectra of Karanjin.

$\delta 60.9,104.09,109.82,116.82,119.47,121.64,128.18$, $128.48,130.52,130.73,141.58,145.57,149.64,154.55$, $157.86,174.48$

Table 5: spectra matching to each carbon in Karanjin.

\begin{tabular}{|c|c|c|c|}
\hline $\begin{array}{c}\text { Sr. } \\
\text { No. }\end{array}$ & Dept & $\boldsymbol{\delta}$ (ppm) & Assignment \\
\hline 1 & CH3 & 60.9 & C11 \\
\hline 2 & CH & 104.09 & C3’ \\
\hline 3 & CH & 109.82 & C2' \\
\hline 4 & Quaternary & 116.82 & C8 \\
\hline 5 & Quaternary & 119.47 & C1” \\
\hline 6 & CH & 121.64 & C4” \\
\hline 7 & CH & 128.18 & C3” \\
\hline 8 & CH & 128.48 & C5” \\
\hline 9 & CH & 130.52 & C6” \\
\hline 10 & CH & 130.73 & C2” \\
\hline 11 & Quaternary & 141.58 & C10 \\
\hline 12 & CH & 145.57 & C5 \\
\hline 13 & Quaternary & 149.64 & C9 \\
\hline 14 & Quaternary & 154.55 & C2 \\
\hline 15 & Quaternary & 157.86 & C3 \\
\hline 16 & Quaternary & 174.48 & C4 \\
\hline 17 & CH & 146.82 & C6 \\
\hline 18 & CH & 128.2 & C7 \\
\hline
\end{tabular}

\section{- Visualization of UV}

Observe the plate under UV light at $366 \mathrm{~nm}$. Note the Rf and colour of the resolved bands. 


\section{- Evaluation TLC}

A band (Rf 0.58) corresponding to karanjin is visible in both test and standard solutions as a fluroscent blue band when observed under UV light at $366 \mathrm{~nm}$.

Table 6: TLC Details of Test Solution of Pongamia pinnata $L$. seeds.

\begin{tabular}{|ll|}
\hline Rf Value & Colour of the band \\
\hline 0.11 & Blue \\
\hline 0.23 & White \\
\hline 0.36 & Fluorescent White \\
\hline 0.48 & Fluorescent White \\
\hline 0.58 & Fluorescent White \\
\hline Karanjin & \\
\hline 0.77 & Fluorescent White \\
\hline 0.92 & Blue \\
\hline
\end{tabular}

\section{- Mass spectrum}

Mass spectrum could not be recorded as Karanjin does not elute under Gas-Chromatographic conditions used for mass spectrometry.

\section{CONCLUSION}

A simple viable method has been standardized for isolation of karanjin from $P$. pinnata seed oil where in higher yield of karanjin purity $99.623 \%$ was achieved and the product was stored in a sample vial and it was sealed with Para foil as well as aluminum foil to avoid photoreaction with sunlight, also, it would help pharmaceutical industry, for this molecule in pure form would be more useful in understanding of mechanism of its action instead of crude extract of the seed.

\section{REFERENCES}

[1] O. N. Allen, E. K. Allen, “The leguminosae,” The University of Wisconsin Press; p. 812, 1981.

[2] V. V. Chopade, A. N. Tankar, V. V. Pande, A. R. Tekade, N. M. Gowekar, S. R. Bhadari, S. N. Khandake, "International J. of Green Pharmacy,” April- June, 2008.

[3] S. A. Dahanukar, R. A. Kulkarni, N. N. Rege, "Pharmacology of medicinal plants and natural products," Indian Journal of Pharmacology; 32: S81-S118, 2000.

[4] C. Orwa, A, Mutua, R. Kindt, R. Jamnagass, S. Anthony, “Agroforest tree Database,"; 491p, 2009.

[5] B. Meera, S. B. Kalidhar, "Chemical components of Pongamia pinnata L,” J Ind Chem Soc; 81: 891-892, 2004.

[6] M. Bimla, S. Kumar, S. B. Kalidhar, "A review of chemistry and biological activity of $P$. pinnata," J Med Arom Plant Sci 25: 441-465.

[7] P. Lakshmni, G. Srimannaragana, S. N. V. Rao, "Pongaflavone, a new chromenochromone and an analog of karanjin isolated from Pongamia pinnata,” Indian J Chem; 12: 8-9, 1974.

[8] R. N. Khanna, T. R. Seshadri. "Pongaglabrone, a new component of the seeds of Pongamia glabra, its constitution and synthesis,” Tetrahedron; 19: 219-225, 1963.

[9] K. Simin Shameel, M. UsmanGhani, S. Ali and V. U. Amad, "Chemical constituents from the Seed of Pongamia Pinnata (L.) Pirre,” Pakistan Journal of Pharmaceutical SCIENCES January, 9 ,: 11-20, 1996.

[10]S. Koysomboon, I. Van Altena, S. Kato, K. Chantrapromma, "Antimycobacterial flavonoids from Derris indica,". Phytochemistry 67: 1034-1040, 2006.

[11] H. G. Champion, S. K. Seth, "Revised Survey of Forest Types of India,” Manager of Publication, GOl, New Delhi, 1968.

[12] B. J. Vinay, T. C. Sindhu Kanya, "Effect of detoxification on functional and nutritional quality of proteins of karanja seed meal,”. Food Chem. 106, 77-84, 2008.

[13]T. Prabha. M. Dorababu, G. Shalini, P. K. Agarwal, V. K. Joshi, R. K. Goel, "effect of methanolic extract of p. pinniata linn seed on gastro duodenal ulceration and mucosal offensive factors in rats," Indian Journal of Experimental Biology August, 47, 649-659, 2009.

[14] M. M. Essa, S. Perumal, S. Ganapathy, M. Tamilarasan, B. D. Kadiyala, "protective influence of p. pinnata on blood ammonia and urea levels in ammonium chloride induced hyperammonemia,”, J. Appl. Biomed,3: 1-5, 2005.

[15] M. Raghavendra, A. Trigunayat, R. K. Singh, S. Mitra, R. K. Goel, R, K. Acharrya, "effect of ethanolic extrac of root of pongamia pinnata Pongamia pinnata on stress, behavioral and histopathological alterations induce by cerebral ischemia,” AlI Indian Journal of Experimental Biology , October, 45: 868876, 2007.

[16] P. P. Joy, J. Thomas, S. Mathew, P. Skaria, “Aromatic and Medicinal Plants Research Station Odakkali, Asamannoor P.O., Ernakulam District, Kerala, India,”

[17] U. D. din Q, N. Parveen, N. U. Khan, K. C. Singhal, "Antifilarial potential of the fruits and leaves extracts of Pongamiapinnata on cattle filarial parasite," Setariacervi. PhytotherRes 17: 1104-1107, 2003.

[18] M. Elanchezhiyan, S. Rajarajan, P. Rajendran, S. P. Thyagarajan, "Antiviral properties of the seed extract of an Indian medicinal plant P. Pinnata against herpes simplex viruses in vitro studied on vero cells,” J Med. Microbiol,38: 262-264, 1993.

[19]S. Lakshmni, "The Wealth of India A Ready Reckoner on Biodiversity and Bioresources of India," NISCAIR, CSIR, New Delhi, India, 2003.

[20]C. P. Khare, "Indian Medicinal Plants, an illustrated dictionary," Springer-verlag Berlin/Heidelberg, New York, USA, 2004.

[21] R. P. Rastogi, B. N. Mehrotra, "Compendium of Indian medicinal plant," Central Drug Research Institute and Publication and information Directorate, New Delhi, India, 1993.

[22] G. Ahmad, P. P. Yadav, R. Maurya "Furanoflavonoid glycosides from Pongamiapinnata fruits,” Phytochemistry 65: 921-924,2004.

[23] S. K. Talapatra, A. K. Mallik, B. Talapatra, "Pongaglabol, a new hydroxyfuranoflavone, and aurantiamide acetate, a dipeptide from the flowers of Pongamiaglabra," Phytochemistry 19: 1199-1202, 1980.

[24] R. P. Rastogi, B. N. Mehrotra, S. Sinha, P. Pant, R. Seth R, "Compendium of Indian medicinal plants," Central Drug Research Institute and Publications \& Information Directorate, New Delhi, India, 2011.

[25] L. Li , X. Li, C. Shi, Z. Deng, H. Fu, "Pongamone A-E, five flavonoids from the stems of a mangrove plant, Pongamiapinnata,” Phtochemistry 67: 1347- 1352, 2006.

[26] K. R. Kritikar, B. D. Basu, "Indian Medicinal Plants,” $2^{\text {nd }}$ edn. International Book Distributions, Dehradune, India, 1995.

[27] L. D. Kapur, “Traditional uses of medicinal plants,” Ayurvedic Medicinal plants 327, 2001.

[28] R. K. Singh, V. K. Joshi, R. K. Goel, S. S. Gambhir, S. B. Acharya, "Pharmacological action of P. pinnata seed -A preliminary study,” Ind J ExpBiol 34:1204-1207. 1996.

[29] R. Punitha, K. Vasudevan, S. Manoharan, "Effect of Pongamia pinnata flowers on blood glucose and oxidative stress in alloxan induced diabetic rats," Ind J Pharmacol38: 62-63, 2006.

[30] T. Prabha, M. Dora Babu, S. Priyambada, V. K. Agrawal, R. K. Goel, "Evaluation of Pongamia pinnata root extract on gastric ulcers and mucosal offensive and defensive factors in rats,” Ind J ExpBiol41: 304-310, 2003. 